
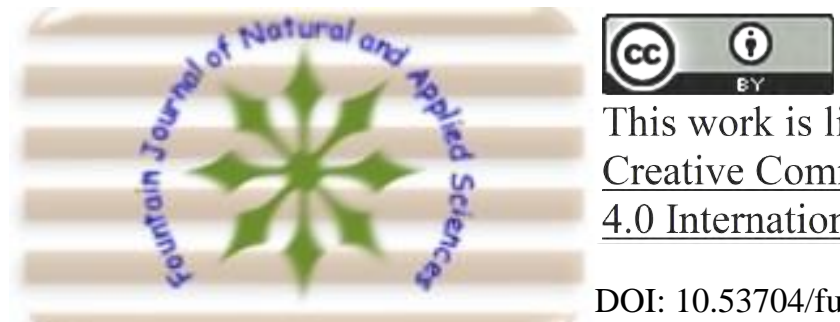

This work is licensed under Creative Commons Attribution 4.0 International License.

DOI: 10.53704/fujnas.v8i1.298

A publication of College of Natural and Applied Sciences, Fountain University, Osogbo, Nigeria. Journal homepage: www.fountainjournals.com ISSN: 2354-337X(Online),2350-1863(Print)

\title{
Factor Analysis Techniques for the Assessment of Water Quality: A Case Study of Okun River, Ilorin, Kwara State
}

\author{
*Okoro, H. K., Adebayo, G. B., Saliu, O.D and Adebayo, A. O. \\ Department of Industrial Chemistry, Material and Environmental-Analytical Research Group, Faculty of Physical Sciences, \\ University of Ilorin, Ilorin, Nigeria.
}

\begin{abstract}
Okun River caters for diverse needs. Resulting from rapid industrialization and urbanization, the quality of the river is significantly affected. The study of impact of discharged industrial wastewaters into Okun River was carried out. Physicochemical properties such as temperature, turbidity, conductivity, total suspended solids, total dissolved solids, colour, odour, $\mathrm{pH}$, total hardness, chloride, and concentrations of heavy metals (chromium, manganese, iron, copper, zinc and cadmium) were assessed. The mean concentrations of heavy metals and the physicochemical parameters determined were compared with standards and tolerance limit. $\mathrm{Cr}$ was not detected in all the samples while $\mathrm{Mn}, \mathrm{Fe}, \mathrm{Cu}, \mathrm{Zn}$ and $\mathrm{Cd}$ concentrations varied from $0.10-3.47 \mathrm{mg} / \mathrm{L}, 2.64-9.65 \mathrm{mg} / \mathrm{L}, 0.37-3.79 \mathrm{mg} / \mathrm{L}, 0.22-1.53 \mathrm{mg} / \mathrm{L}$ and $0.00-$ $0.03 \mathrm{mg} / \mathrm{L}$ respectively. The mean values of $\mathrm{pH}$, temperature, conductivity, turbidity, TSS, TDS, total hardness and chloride ranged between 6.33-7.77, 25.0-29.0 ${ }^{\circ} \mathrm{C}, 325-815 \mathrm{mS} / \mathrm{cm}, 14.80-209.33 \mathrm{NTU}$, 733.33-1033.33 mg/L, 133-395.67 mg/L, 137.50-962.50 mg/L and 11.52- $49.04 \mathrm{mg} / \mathrm{L}$ respectively. The principal component analysis confirmed the heavy metals to be from anthropogenic and industrial origin.
\end{abstract}

Keywords: Industrial effluents, physicochemical parameters, water quality, heavy metals, component analysis

\section{Introduction}

Most organic industrial wastewaters are produced by factories producing (cosmetics, synthetic detergents, glue and adhesives, brewery and fermentation factories, pharmaceuticals, soaps, pesticides and herbicides, tanneries and leather factories, textile factories, organic dyes-stuffs, metal processing industries and oil refining industries) (Hanchang, 2009). Wastewater containing organic pollutants like pesticides, hydrocarbons, phenolic compounds, plasticizers, fertilizers, oil and greases, pharmaceuticals, detergents contain large amount of suspended solids which reduces the rays of light available to aquatic organisms and also makes the aquatic habitat unsuitable for invertebrates after settling out (Akl et al., 2014). It has been observed that inorganic industrial wastewater produced in the coal and steel industry, in the non-metallic minerals industries, and industries for the surface processing of metals and in commercial enterprises contribute to the decadence of safety index of the environment (Hanchang, 2009).

*Corresponding author: 07032370228

Email address: hkoadeola@gmail.com 
One of the most critical problems of developing countries is improper management of the large amount of waste products generated by various anthropogenic activities. The disposal of the wastes into the ambient environment especially water bodies has been observed to pose great challenge, and it has rendered these natural resources unsuitable for both primary and secondary usage (Aboyeji, 2013; Okoro et al., 2018). Despite the environmental consequences of surface water pollution by industrial effluents, industrial effluents are still contaminating many river systems in developing countries, especially Nigeria (Etim \& Onianwa, 2013). Industrial effluent contamination of natural water bodies has emerged as a major challenge in developing and densely populated countries like Nigeria. Estuaries and inland water bodies, which are the major sources of drinking water in Nigeria, are often contaminated by the activities of the adjoining populations and industrial establishments (Ikhajiagbe et al., 2014).

Most major industries have treatment facilities for industrial effluents, but this is not the case with small-scale industries, which cannot afford sustainable investments in pollution control equipment, as their profit margin is very slender (Singh, 2012). Hence, there are issues of these industrial wastes management, which later becomes menacing concern after accumulations. The heavy metals are very harmful, toxic and poisonous even in parts per billion (ppb) range. These toxic heavy metals released in aquatic environment may enter into the food chain through bio-magnification that may cause various health problems in humans (Akaninwor et al., 2009). Ultimately, metallic components leach to groundwater, lead to contamination due to accumulation, and may cause series problems for living things. Another recent investigation reported that elevated levels of heavy metals in seafood are found from the areas having long-term uses of treated or untreated wastewater (Kisku et al., 2016).

Heavy metals are defined subset of metallic elements having atomic weights between 63.546 gram and 200.590 gram and a specific gravity greater than 4.0, i.e. at least 5 times that of water. They exist in water in colloidal, particulate, dissolved phase with their occurrence in water bodies being of natural, or of anthropogenic origin and some of them are essential to sustain normal body functions. In addition, cobalt, copper, iron, manganese, molybdenum and zinc are needed at low levels as catalyst for enzyme activities. Heavy metals can also include the transition metals, some metalloids, lanthanides, and actinides and they have been associated with contamination and potential toxicity or eco-toxicity (Onwughara et al., 2011). The major anthropogenic sources of heavy metals are industrial wastes from mining sites, manufacturing and metal finishing plants, and domestic wastewater and run off from roads. Many of these trace metals, such as Mercury, Lead, Cadmium, Nickel, Arsenic, and Tin are highly toxic to humans. Some heavy metals such as $\mathrm{Hg}, \mathrm{Pb}, \mathrm{As}$, $\mathrm{Cd}, \mathrm{Fe}, \mathrm{Co}, \mathrm{Mn}$, and $\mathrm{Cr}$ among others have been identified as harmful to aquatic ecosystem and human health (AbdulJameel et al., 2012; Okoro et al., 2013; Okoro et al., 2017).

Treatment of all kinds of wastewater before their discharge into the environment is important in order to avoid pollution. Large quantities of untreated solid and liquid wastes are discharged without control into streams and rivers, particularly those flowing through towns, cities and villages. In this way, water that should be a blessing to life becomes a carrier of poisons, toxicants and pathogens leading to dreadful diseases that cause death. Many diseases and premature deaths can be prevented by adequate care of our environment (Olaniyi et al., 2012).

This study was carried out to investigate the impacts of industrial effluents on the water quality of Okun river, using factor analysis and multivariate statistical techniques, respectively. In addition, it is to be noted that the comparison of the concentrations of each pollutant with national and international effluent standards will be performed. The physicochemical properties determination will show the extent of pollution of Okun River. Therefore, physicochemical properties such as Total Solid (TS), Total Suspended Solids (TSS), colour, Total Hardness, conductivity, alkalinity, acidity, odour, Total Dissolved Solids, Temperature (TDS), turbidity, and chloride among others were investigated in conjunction with determination of $\mathrm{Cr}, \mathrm{Cu}, \mathrm{Mn}, \mathrm{Zn}, \mathrm{Fe}$ and $\mathrm{Cd}$. 


\section{Materials and Methods}

\section{Description of Study Area}

Ilorin, the capital of Kwara state, Nigeria, is the study area for this investigation (Figure 1). It lies between latitude $8^{0} 24^{\prime} \mathrm{N}$ and $8^{0} 36 \mathrm{~N}$ and between longitude $4^{0} 10^{\prime} \mathrm{E}$ and $4^{0} 36^{\prime} \mathrm{E}$ (Kolawole et al., 2011). The city has a humid tropical climate, which is characterised by wet and dry season. Rainy season in the city begins towards the end of March and of October with two peak periods in June and September. Temperature is uniformly high throughout the year and open- air isolation can be very uncomfortable during the dry season (Oriola \& Bolaji, 2012).

The city is mainly drained by river Asa and its tributaries are Aluko, Alalubosa, Okun, Osere, Agba and Atikeke forming the four drainage basins (Olabode et al., 2014). Okun River among others is the river being investigated in this study. Okun River is located on the western part of Asa River. Land use pattern in the basins can be classified into built-up (paved) area, forest covered, farms and fallow area, area covered by grassland and bare surface area (Jimoh \& Iroye, 2010).

\section{Sampling}

The water samples were collected from seven locations as shown in the table 1.

\section{Table 1: Geographical location and position of sampling site.}

\begin{tabular}{|c|c|c|c|c|c|}
\hline$S / N$ & Samples & Study area & $\begin{array}{l}\text { Lattitude } \\
\text { (N) }\end{array}$ & $\begin{array}{l}\text { Longitude } \\
\left.\text { ( }{ }^{\circ} \mathrm{E}\right)\end{array}$ & Activity \\
\hline 1 & $O C$ & $\begin{array}{l}\text { Olorunsogo } \\
\text { Cottage }\end{array}$ & $8.47374 \mathrm{~N}$ & $4,51472 E$ & Car wash \\
\hline 2 & $5 W$ & Saw Mill & $8,47124 \mathrm{~N}$ & $4,52321 \mathrm{E}$ & Saw mill \\
\hline 3 & $O E$ & Oko Erin & $8.47562 \mathrm{~N}$ & $4,53843 \mathrm{E}$ & Dump site \\
\hline 4 & OS & Off Stadium & $8,47444 \mathrm{~N}$ & $4,55244 E$ & Farming \\
\hline 5 & 65 & Global Soap & $8,47248 \mathrm{~N}$ & $4,53019 \mathrm{E}$ & Soap industry \\
\hline 6 & TP & $\begin{array}{l}\text { Tuyil } \\
\text { Pharmacy }\end{array}$ & $8,47601 \mathrm{~N}$ & $4,55244 E$ & $\begin{array}{l}\text { Pharmaceutical } \\
\text { industry }\end{array}$ \\
\hline 7 & UN & Unity road & $8,47901 \mathrm{~N}$ & $4,55881 \mathrm{E}$ & $\begin{array}{l}\text { Forming, } \\
\text { Poultry }\end{array}$ \\
\hline
\end{tabular}

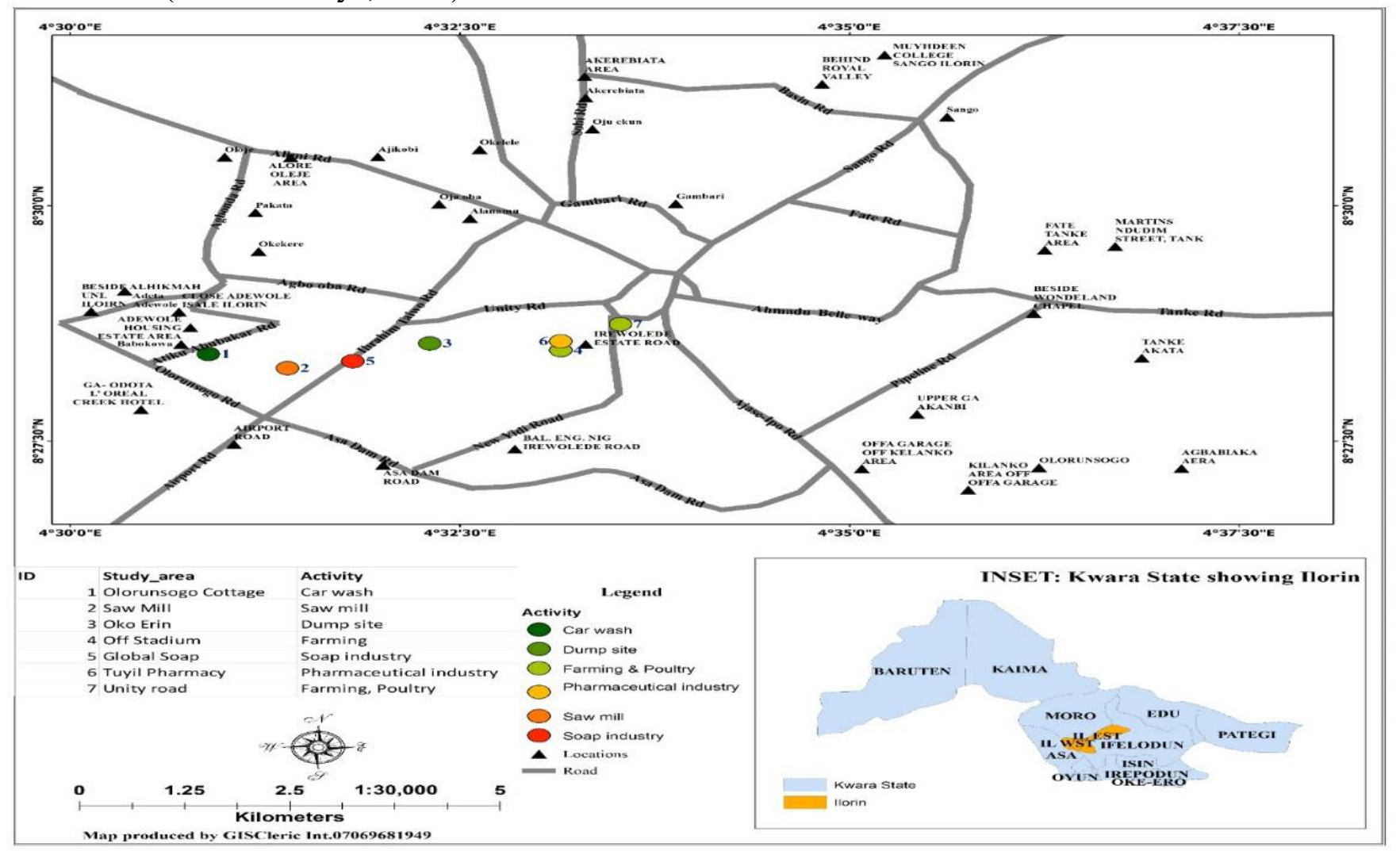

Figure 1: Map Showing the Sample Site. 


\section{Sample digestion}

A $50 \mathrm{~mL}$ aliquot of well-mixed acidified sample was transferred to a $50 \mathrm{~mL}$ centrifuge tube and placed into Mod Block. A $2 \mathrm{~mL}$ of concentrated $\mathrm{HNO}_{3}$ and $1 \mathrm{~mL}$ of concentrated $\mathrm{HCl}$ was added. The sample was covered with a ribbed watch glass (plastic) and heated at $90^{\circ} \mathrm{C}$ until the volume was reduced to $15 \mathrm{~mL}$. A $15 \mathrm{~mL}$ of distilled water was then used to dilute the samples to $30 \mathrm{~mL}$ which were analysed (Hagedorn 2008).

\section{Determination of physicochemical parameters Turbidity}

This was determined using a standardized Hanna H198703 Turbidimeter. The samples were poured into the measuring bottle and the surface of the bottle was wiped with tissue paper. The bottle was then inserted into the turbidimeter and the reading was obtained (Emmanuel \& Chukwudi, 2013). Values were recorded in NTU i.e. Nephelometric Turbidity Unit.

\section{Electrical conductivity}

The Electrical conductivity of the water samples was determined using the conductivity sensor, which was dipped into $20 \mathrm{~mL}$ of water samples in a beaker. It is necessary to correct the readings for changes in temperature so the conductivity meter was adjusted to compensate for temperature changes and correct the readings to a standard $25^{\circ} \mathrm{C}$ (Emmanuel \& Chukwudi, 2013).

\section{pH}

The $\mathrm{pH}$ of the water samples was determined using the Hanna microprocessor $\mathrm{pH}$ meter. It was standardized with a buffer solution of $\mathrm{pH}$ range between 4 and 9 (Emmanuel \& Chukwudi, 2013).

\section{Chloride}

The sample $(25 \mathrm{~mL})$ was measured and diluted to $50 \mathrm{~mL}$ with distilled water. The $\mathrm{pH}$ of the sample was adjusted to 7.5 with $\mathrm{H}_{2} \mathrm{SO}_{4}$ followed by $1 \mathrm{~mL}$ $0.1 \mathrm{M} \mathrm{KCrO}$. The sample was titrated with $0.0141 \mathrm{M} \mathrm{AgNO}_{3}$ standard solution until the colour changed from yellow to faint red. Reagent was titrated blank using only distilled water without the sample (Olaniyi et al., 2012).

\section{Total Hardness}

The sample $(20 \mathrm{~mL})$ was placed in different clean $250 \mathrm{~mL}$ conical flask. To this were added $2 \mathrm{~mL}$ of ammonium chloride in concentrated ammonia buffer $\left(\mathrm{NH}_{4} \mathrm{CL} /\right.$ conc. $\left.\mathrm{NH}_{3}\right)$ and 2 drops of Eriochrome Black $\mathrm{T}$ indicator. This was titrated against $0.01 \mathrm{M}$ EDTA solution until there was a colour change from violet to blue (Olaniyi et al., 2012).

\section{Results and Discussions \\ Heavy Metals}

It can be established from Table 2 and graphical representations (Figure 2) that the concentrations of metals varied in the order of $\mathrm{Fe}>\mathrm{Mn}>\mathrm{Cu}>\mathrm{Zn}>$ $\mathrm{Cd}>\mathrm{Cr}$ in Table 2. The order of magnitude of pollution in the sampling locations for Iron is $5>1$ $>3>2>6>4>7$; Copper is $2>1>6>3>4>7$ $>5$, Manganese is $1>5>2>3>6>7>4$; Zinc is $7>2>6>5>3>1>4$ and Cadmium is $1>5>6$ $>7>4>2>3$ respectively.

From Table 2, it can be deduced that Chromium was not detected at all the sampling points in Okun River. Similar result was obtained on surface and ground waters concentrations of metal elements and their suitability for fish culture in central CrossRiver State (Ada et al., 2012). The absence of chromium might be due to the absence of significant geological distribution of minerals in the sites (Adefemi \& Awokunmi, 2010; Ada et al., 2012). Except for locations 1 and 5, Cd was detected at all sampling locations with mean values that ranged between $0.01 \mathrm{mg} / \mathrm{L}$ and $0.03 \mathrm{mg} / \mathrm{L}$. All the obtained values of the heavy presented in Table 3 exceeded WHO (2008) and USEPA (2009) standard limits of $0.003 \mathrm{mg} / \mathrm{L}$ and $0.005 \mathrm{mg} / \mathrm{L}$ respectively but were within the permissible limit set by FEPA (2001) except the value obtained at location 3. A corresponding trend was also obtained on heavy metals concentration in surface water, sediments, fish and Periwinkles of Lagos lagoon (Aderinola et al., 2009). The cadmium present suggests the effect of pollution due to dyes and drug complexes, however there are few recorded cases of cadmium poisoning in human beings (Lokhande et al., 2011). 
Table 2: Concentrations (mg/L) of Heavy metals in Okun River.

\begin{tabular}{|c|c|c|c|c|c|c|}
\hline \multirow{2}{*}{$\begin{array}{l}\text { Study } \\
\text { area }\end{array}$} & \multicolumn{6}{|c|}{ Heavy metals (mg/L) } \\
\hline & $\mathrm{Cr}$ & Mn & $\mathbf{F e}$ & $\mathbf{C u}$ & Zn & Cd \\
\hline 1 & ND & $0.10 \pm 0.01$ & $4.89 \pm 1.38$ & $0.51 \pm 0.02$ & $1.06 \pm 0.09$ & $0.00 \pm 0.00$ \\
\hline 2 & ND & $0.80 \pm 0.01$ & $7.50 \pm 7.49$ & $0.37 \pm 0.09$ & $0.55 \pm 0.28$ & $0.02 \pm 0.01$ \\
\hline 3 & ND & $0.92 \pm 0.10$ & $5.98 \pm 3.49$ & $0.55 \pm 0.20$ & $0.43 \pm 0.36$ & $0.03 \pm 0.01$ \\
\hline 4 & ND & $3.47 \pm 0.16$ & $9.00 \pm 6.32$ & $0.91 \pm 0.98$ & $1.53 \pm 1.53$ & $0.02 \pm 0.01$ \\
\hline 5 & ND & $0.20 \pm 0.01$ & $2.64 \pm 1.17$ & $3.79 \pm 6.00$ & $0.63 \pm 0.48$ & $0.00 \pm 0.00$ \\
\hline 6 & ND & $1.19 \pm 0.25$ & $7.89 \pm 5.70$ & $0.70 \pm 0.59$ & $0.63 \pm 0.34$ & $0.01 \pm 0.01$ \\
\hline 7 & ND & $2.23 \pm 0.49$ & $9.65 \pm 10.96$ & $0.90 \pm 0.91$ & $0.22 \pm 0.12$ & $0.02 \pm 0.01$ \\
\hline
\end{tabular}

ND: Not detected.

Table 3: Concentrations (mg/L) of Heavy metals in examined water samples by regulatory bodies and past research work on surface water.

\begin{tabular}{lllllll}
\hline $\begin{array}{l}\text { Regulatory } \\
\text { Bodies/ } \\
\text { Research work }\end{array}$ & Cr & Mn & Fe & Cu & Zn & Cd \\
\hline $\begin{array}{llllll}\text { WHO (2008) } \\
\text { USEPA (2009) }\end{array}$ & 0.05 & 0.1 & 0.3 & 2.0 & 5.0 & 0.003 \\
FEPA (2001) & 0.05 & 0.05 & 0.3 & 1.3 & 5.0 & 0.005 \\
$\begin{array}{l}\text { Aderinola et al., } \\
\text { (2009) }\end{array}$ & 0.06 & 0.09 & 1.41 & 0.20 & 0.53 & 0.35 \\
$\begin{array}{l}\text { Kar et al., } \\
\text { (2008) }\end{array}$ & $0.001-$ & $0.025-$ & $0.025-$ & $0.003-$ & $0.012-$ & $0.001-$ \\
$\begin{array}{l}\text { Ada et al., } \\
\text { (2012) }\end{array}$ &.--- & 2.72 & 5.49 & 0.032 & 0.37 & 0.003 \\
Present Study & ND & $0.17-1.27$ & $0.43-2.93$ & $0.76-0.97$ & $0.31-1.28$ & ND \\
\hline
\end{tabular}

Concentration of Mn obtained ranged from 0.10 to $3.47 \mathrm{mg} / \mathrm{L}$. Its mean concentration was ranked second highest after iron at all locations, except for location 5, where it was ranked fourth. These values exceeded the permissible limits set by WHO (2008) and USEPA (2009), but were lower than FEPA (2001) standard. All the values, except at locations 4 and 7, corresponded to the values obtained by Ada et al. (2012). The mean concentrations of $\mathrm{Cu}$ obtained varied between 0.37 and $3.79 \mathrm{mg} / \mathrm{L}$. All the values were found to be much lower than the WHO (2008), USEPA (2009) standards and the permissible limit set by FEPA (2001) except at location 3 with a mean concentration of $3.79 \mathrm{mg} / \mathrm{L}$, which deviated widely from all the standard limits set by all the regulatory bodies.
Table 4: Extracted Eigen vectors of heavy metals in Okun River.

\begin{tabular}{ccc}
\hline & $\begin{array}{c}\text { Coefficients } \\
\text { of PC1 }\end{array}$ & $\begin{array}{c}\text { Coefficients of } \\
\text { PC2 }\end{array}$ \\
\hline $\mathbf{C r}$ & 0 & 0 \\
$\mathbf{M n}$ & 0.52439 & 0.37114 \\
& & \\
$\mathbf{F e}$ & 0.57606 & -0.10852 \\
$\mathbf{C u}$ & -0.47763 & 0.39495 \\
$\mathbf{Z n}$ & 0.18794 & 0.79283 \\
$\mathbf{C d}$ & 0.36017 & -0.25675 \\
\hline
\end{tabular}

Concentrations of $\mathrm{Zn}$ obtained in the s present study ranged from $0.22 \mathrm{mg} / \mathrm{L}$ to $1.53 \mathrm{mg} / \mathrm{L}$. All the values obtained complied adequately with $\mathrm{WHO}$ 
(2008) and USEPA (2009) standards as they were below the permissible limits of $5.0 \mathrm{mg} / \mathrm{L}$ set by these regulatory bodies. However, they exceeded the FEPA (2001) $1 \mathrm{mg} / \mathrm{L}$ permissible limit. This moderate level of $\mathrm{Zn}$ was attributed to the absence of heavy discharge from zinc-based fertilizer chemicals (Adefemi \& Awokunmi, 2010; Ada et al., 2012; Kar et al., 2008). The mean concentrations of iron obtained ranged from 2.64 $\mathrm{mg} / \mathrm{L}$ to $9.65 \mathrm{mg} / \mathrm{L}$ and varied widely from one another. All the values deviated widely from WHO (2008) and USEPA (2009) standards but were below the permissible limit of $20 \mathrm{mg} / \mathrm{L}$ set by FEPA (2001). Concentration of iron was the highest among all the metals assessed, except at location 5 where copper had a greater mean concentration. The high concentration of iron obtained at location 5 might be due to the soap effluents being released into the river at this point.

With respect to the principal component analysis for the heavy metal content of Okun River in Table 4, two PCs were extracted using the correlation matrix which reflected the process influencing the heavy metal composition of the river water (Boyacioglu et al., 2007). The sources of PC1 loading variables is the industrial and anthropogenic sources while the source of PC2 is loading represent geological and other pollution sources. The PCs extracted from the variables were retained with eigen values greater than 1.11 and the variance of the PCs are $40.49 \%$ and $18.59 \%$ respectively as presented in Figure 2 (Anazawa et al., 2004). PC1 is strongly correlated with $\mathrm{Mn}, \mathrm{Cd}$ and $\mathrm{Fe}$ and negatively correlated with $\mathrm{Cu}$. PC2 is strongly correlated with $\mathrm{Zn}, \mathrm{Cu}, \mathrm{Mn}$ while negatively correlated with $\mathrm{Fe}$ and $\mathrm{Cd}$. Therefore, we can confirm from the statistical data that larger percentage of the heavy metals are from industrial sources (Chu et al., 2018)

The loading plot (Figure 2) and the correlation matrix (Table 5) helps to explain the level of correlation between the heavy metals. $\mathrm{Mn}, \mathrm{Fe} ; \mathrm{Cu}$, $\mathrm{Fe}$; are strongly correlated and $\mathrm{Mn}, \mathrm{Zn} ; \mathrm{Mn}, \mathrm{Cd} ; \mathrm{Fe}$, $\mathrm{Cd}$; $\mathrm{Cd}, \mathrm{Mn}$; are moderately correlated while $\mathrm{Mn}$, $\mathrm{Cu}$; $\mathrm{Fe}, \mathrm{Cu} ; \mathrm{Cu}, \mathrm{Cd} ; \mathrm{Zn}, \mathrm{Cu}$; are negatively correlated. On the loading plots, when the two vectors are close, forming a small angle, the two vectors they represent are positively correlated. If they diverge at very large angles, they are negatively correlated the sources of PC1 loading variables is the industrial and anthropogenic sources while the source of PC2 is loading represent geological and other pollution sources (Chu et al., 2018).

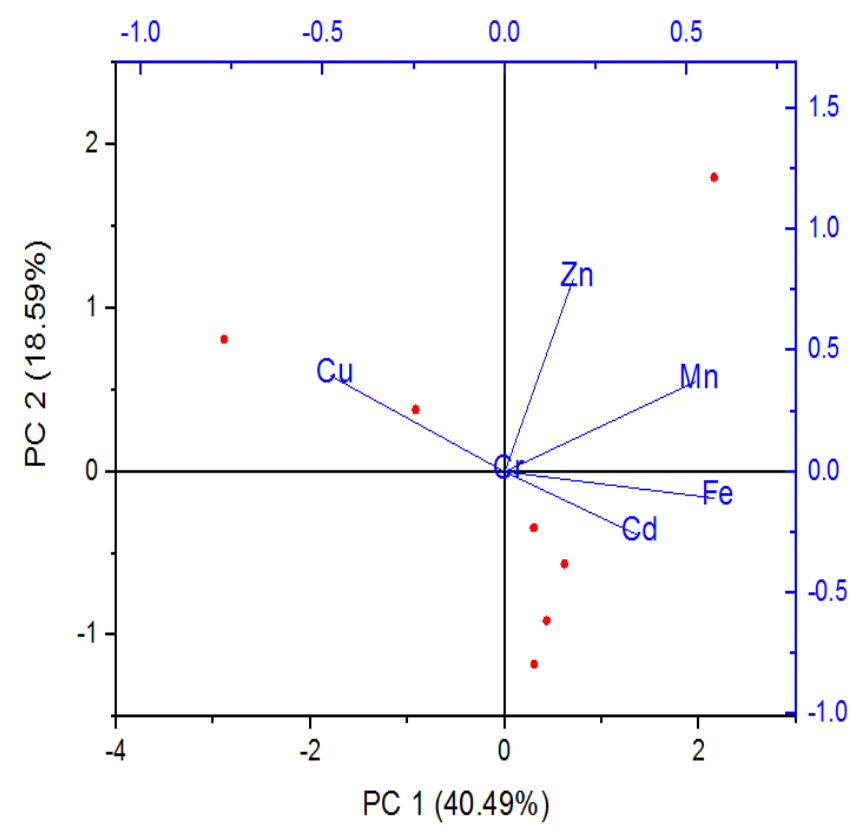

Figure 2: Bi-plot of Okun River heavy metals

Table 5: Correlation matrix of the heavy metals in Okun river.

\begin{tabular}{lllllll}
\hline & $\mathbf{C r}$ & $\mathbf{M n}$ & $\mathbf{F e}$ & $\mathbf{C u}$ & $\mathbf{Z n}$ & $\mathbf{C d}$ \\
\hline $\mathbf{C r}$ & 0 & 0 & 0 & 0 & 0 & 0 \\
$\mathbf{M n}$ & 0 & 1 & 0.79909 & -0.25815 & 0.37741 & 0.26396 \\
$\mathbf{F e}$ & 0 & 0.79909 & 1 & -0.65175 & 0.01591 & 0.25036 \\
$\mathbf{C u}$ & 0 & - & -0.65175 & 1 & - & - \\
& & 0.25815 & & & 0.05609 & 0.44819 \\
$\mathbf{Z n}$ & 0 & 0.37741 & 0.01591 & -0.05609 & 1 & 0.09665 \\
$\mathbf{C d}$ & 0 & 0.26396 & 0.25036 & -0.44819 & 0.09665 & 1 \\
\hline
\end{tabular}




\section{Physicochemical Parameters}

All the water samples were coloured except samples gotten from points 1, 2 and 3 at Location 1 were colourless. However, the apparent colours observed varied between different shades of black, brown and yellow. The odours recorded for the samples were observed to be within four fruity, earthy, offensive and medicinal with the majority of the samples falling in the earthy category. Table 6 show the obtained Physiochemical parameters for the Okun River.

$\mathrm{pH}$ is a measure of the acidity or alkalinity of water and an extremely significant parameter in accounting for the toxicity of heavy metals. Thus, $\mathrm{pH}$ has a primary importance in deciding the quality of wastewater effluent. The $\mathrm{pH}$ values of the samples varied between 6.3 and 7.9 with the lowest value recorded at location 5 while the highest at location 2 . All the values complied with both WHO (2008), USEPA (2009) and FEPA (2001) permissible limits for surface water (Adewoye, 2013). Many lake and rivers exhibit vertical temperature gradients as the sun warm the upper water while deeper water will remain cooler (Wahl $\&$ Peters, 2014). The mean temperature values ranged between $25{ }^{\circ} \mathrm{C}$ and $29{ }^{\circ} \mathrm{C}$ with the highest values recorded at locations 2 and 5. However, all the values complied with WHO (2008), USEPA (2009) FEPA (2001) permissible limits for surface water. These values are also similar to the values obtained on Asa River (Adewoye, 2013) Electrical conductivity (EC) in natural waters is the normalized measure of the water's ability to conduct electric current. Dissolved salts, such as sodium chloride and potassium chloride, mostly influence this. Most freshwater sources range between 0.001 to $0.1 \mathrm{~S} / \mathrm{m}$. The source of EC may be an abundance of dissolved salts due to poor irrigation management, minerals from rainwater run-off, or other discharges, presence of free $\mathrm{CO}_{2}$ and level of hardness in the water (Adefemi \& Awokunmi, 2010). The mean values obtained for conductivity ranged between $325.33 \mathrm{mS} / \mathrm{cm}$ and $815.67 \mathrm{mS} / \mathrm{cm}$. The mean values were complied with only the USEPA (2009) standard limit, as other regulatory bodies are silent on permissible limits for conductivity in surface water.

Monitoring of TSS is an important criterion for assessing the quality of water. Surface water may contain suspended solid matter consisting of particles of many different sizes. These small solid particles cause the liquid to appear turbid. The values obtained for turbidity ranged from 14.80 to 209.33 NTU. The highest value was recorded at location 5 while the lowest at location 6 . All the values exceeded the permissible limit set by FEPA (2001). All these values, except for values recorded at locations 2 and 5, corresponded to the values obtained for Asa River (Adewoye, 2013). The sources of total suspended solids include erosion, storm water runoff, industrial discharges, microorganisms, and eutrophication. Many fish species are sensitive to prolonged exposure to TSS.; The mean values obtained for TSS varied between 1033.33 and $733.33 \mathrm{mg} / \mathrm{L}$, with the highest value recorded at location 1 , while the lowest value was obtained at location 6 . All the values correspond to the WHO (2008) standard of $1000 \mathrm{mg} / \mathrm{L}$.

Table 6: Levels of Physicochemical Parameters of water from Okun River.

\begin{tabular}{|c|c|c|c|c|c|c|c|c|}
\hline \multirow{2}{*}{$\begin{array}{l}\text { Study } \\
\text { area }\end{array}$} & \multicolumn{8}{|c|}{ Parameters } \\
\hline & pH & $\begin{array}{l}\text { Temp } \\
\left({ }^{\circ} \mathrm{C}\right)\end{array}$ & $\begin{array}{l}\mathrm{ECS} \\
(\mathrm{ms} / \mathrm{cm})\end{array}$ & $\begin{array}{l}\text { Turbidity } \\
\text { (NTU) }\end{array}$ & $\begin{array}{l}\text { TSS } \\
(\mathrm{mg} / \mathrm{L})\end{array}$ & $\begin{array}{l}\text { TDS } \\
(\mathrm{mg} / \mathrm{L})\end{array}$ & $\begin{array}{l}\text { Total } \\
\text { Hardness } \\
\text { (mg/L) }\end{array}$ & $\begin{array}{l}\text { Chloride } \\
(\mathrm{mg} / \mathrm{L})\end{array}$ \\
\hline 1 & 6.70 & 25.0 & 325.67 & 15.42 & 1033.33 & 133.00 & 137.50 & 11.52 \\
\hline 2 & $\frac{ \pm 0.1}{7.77}$ & $\begin{array}{l} \pm 0.0 \\
28.7\end{array}$ & $\begin{array}{l} \pm 13.05 \\
506.33\end{array}$ & $\begin{array}{l} \pm 9.43 \\
64.43\end{array}$ & $\begin{array}{l} \pm 115.47 \\
1000.00\end{array}$ & $\begin{array}{l} \pm 4.36 \\
228.33\end{array}$ & $\begin{array}{l} \pm 12.50 \\
962.50\end{array}$ & $\begin{array}{l} \pm 2.35 \\
28.36\end{array}$ \\
\hline $\mathbf{3}$ & $\begin{array}{l} \pm 0.15 \\
7.23\end{array}$ & $\begin{array}{l} \pm 0.6 \\
27.0\end{array}$ & $\begin{array}{l} \pm 5.51 \\
421.33\end{array}$ & $\begin{array}{l} \pm 6.83 \\
16.17\end{array}$ & $\begin{array}{l} \pm 100.00 \\
866.67\end{array}$ & $\begin{array}{l} \pm 2.08 \\
204.67\end{array}$ & $\begin{array}{l} \pm 62.50 \\
187.50\end{array}$ & $\begin{array}{l} \pm 0.89 \\
21.57\end{array}$ \\
\hline 4 & $\begin{array}{l} \pm 0.06 \\
6.63\end{array}$ & $\begin{array}{l} \pm 0.0 \\
27.7\end{array}$ & $\begin{array}{l} \pm 40.38 \\
815.33\end{array}$ & $\begin{array}{l} \pm 2.40 \\
21.70\end{array}$ & $\begin{array}{l} \pm 115.47 \\
766.67\end{array}$ & $\begin{array}{l} \pm 2.08 \\
395.67\end{array}$ & $\begin{array}{l} \pm 0.00 \\
233.33\end{array}$ & $\begin{array}{l} \pm 3.58 \\
49.04\end{array}$ \\
\hline & \pm 0.06 & \pm 0.6 & \pm 10.02 & \pm 2.86 & \pm 28.87 & \pm 1.15 & \pm 14.43 & \pm 0.51 \\
\hline 5 & 6.33 & 29.0 & 384.67 & 209.33 & 1000.00 & 170.33 & 195.83 & 10.64 \\
\hline 6 & $\begin{array}{l} \pm 0.06 \\
6.50\end{array}$ & $\begin{array}{l} \pm 0.0 \\
28.3\end{array}$ & $\begin{array}{l} \pm 7.09 \\
525.00\end{array}$ & $\begin{array}{l} \pm 34.53 \\
14.80\end{array}$ & $\begin{array}{l} \pm 0.00 \\
733.33\end{array}$ & $\begin{array}{l} \pm 2.08 \\
242.00\end{array}$ & $\begin{array}{l} \pm 40.18 \\
204.17\end{array}$ & $\begin{array}{l} \pm 0.89 \\
16.16\end{array}$ \\
\hline 7 & $\begin{array}{l} \pm 0.10 \\
6.57 \\
\pm 0.06\end{array}$ & $\begin{array}{l} \pm 0.6 \\
26.0 \\
\pm 0.0\end{array}$ & $\begin{array}{l} \pm 3.61 \\
535.00 \\
\pm 6.24\end{array}$ & $\begin{array}{l} \pm 2.08 \\
18.07 \\
\pm 5.51\end{array}$ & $\begin{array}{l} \pm 57.74 \\
850.00 \\
\pm 0.00\end{array}$ & $\begin{array}{l} \pm 1.73 \\
243.67 \\
\pm 0.58\end{array}$ & $\begin{array}{l} \pm 19.09 \\
198.50 \\
\pm 20.48\end{array}$ & $\begin{array}{l} \pm 2.12 \\
23.93 \\
\pm 0.89\end{array}$ \\
\hline
\end{tabular}


Total dissolved solids (TDS) content in water is a measure for salinity. A large number of salts are found dissolved in natural waters, the common ones are carbonates, bicarbonates, chlorides, sulphates, phosphates, and nitrates of calcium, magnesium, sodium, potassium, iron, and manganese, etc. A high content of dissolved solid elements affects the density of water and osmoregulation of freshwater organisms, reduces solubility of gases (like oxygen) and utility, of water for drinking, irrigational, and industrial purposes. The values obtained for TDS ranged between $133 \mathrm{mg} / \mathrm{L}$ and $397 \mathrm{mg} / \mathrm{L}$. The highest values were recorded at location 4 while the lowest values were recorded at location 1 .

Total hardness is the sum of calcium and magnesium hardness, in $\mathrm{mg} / \mathrm{L}$ as $\mathrm{CaCO}_{3}$ (Campbell $\&$ Peterson, 2010). High levels of hard-water ions such as $\mathrm{Ca}^{2+}$ and $\mathrm{Mg}^{2+}$ can cause scaly deposits in plumbing, appliances, and boilers. These two ions also combine chemically with soap molecules, resulting in decreased cleansing action. Total hardness values obtained ranged between $137.50 / \mathrm{L}$ and $967.50 \mathrm{mg} / \mathrm{L}$. The highest values were recorded at locations 2 while the lowest values between were recorded at locations 1. Values below $200 \mathrm{mg} / \mathrm{L}$ obtained at all points locations 1, 3 and 5 complied with WHO (2008), USEPA (2009) and FEPA (2001) standards, while values above $200 \mathrm{mg} / \mathrm{L}$ obtained at locations 2, 4 and 6 failed to comply with all the standard limits. Chloride values obtained ranged between $10.64 \mathrm{mg} / \mathrm{L}$ and 49.04 $\mathrm{mg} / \mathrm{L}$. The highest values were recorded at location 5 while the lowest value were recorded at Locations 5. High chloride content has a corrosive effect on metal pipes and structures and is also harmful to trees and plants.

From Table 7, PC1 is strongly correlated with ECS, TDS, and Chloride and negatively correlated with turbidity and TSS. PC2 is strongly correlated with $\mathrm{pH}$ and total hardness while negatively correlated with none of the physiochemical properties. As described from above, therefore, we can confirm from the statistical data that larger percentage of the heavy metals are from industrial sources (Shen et al., 2019).

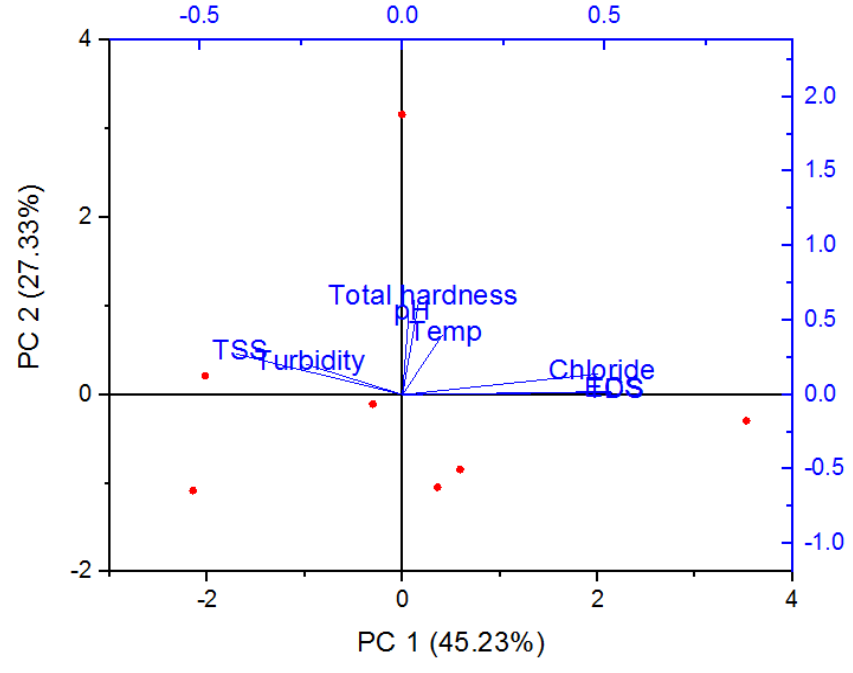

Figure 3: Bi-plot of the physiochemical properties of Okun River

The correlation matrix (Table 8) and the bi-plot (Figure 3) show the correlation relationship between the physiochemical properties. $\mathrm{pH}$ and total hardness are strongly correlated while $\mathrm{pH}$ with temperature, TSS and chloride are moderately correlated. In addition, a negative correlation was seen between $\mathrm{pH}$ and ECS, turbidity and TDS. The significantly positive correlations of temperature and turbidity; ECS and TSS; turbidity and THS; TDS and ECS; chloride and ECS indicates that these variables were influenced by anthropogenic and industrial sources (Shen et al., 2018; Shu et al., 2019).

Table 7: Extracted eigen vectors of the physiochemical properties of Okun river

\begin{tabular}{lcc}
\hline & $\begin{array}{c}\text { Coefficients of } \\
\text { PC1 }\end{array}$ & $\begin{array}{c}\text { Coefficients } \\
\text { of PC2 }\end{array}$ \\
\hline pH & 0.01548 & 0.54038 \\
Temp & 0.0957 & 0.39832 \\
ECS & 0.5139 & 0.02024 \\
Turbidity & -0.237 & 0.20304 \\
TSS & -0.40865 & 0.27206 \\
TDS & 0.51748 & 0.01521 \\
Total & 0.04125 & 0.64349 \\
hardness & & \\
Chloride & 0.48321 & 0.13919 \\
& & \\
\hline
\end{tabular}




\section{Conclusion}

The results of the analysis carried out showed that Okun River is highly polluted, mainly because of anthropogenic activities; especially industrial activities going on around the river. The water samples studied had manganese, copper and iron at high concentrations, which may bio-accumulate in living organisms, posing great environmental and health hazards to aquatic plants and animals, and eventually to man. Zinc and cadmium were also detected in low but potentially hazardous concentrations. On the other hand, the physicochemical properties of the water connote that the water is not fit for domestic and industrial uses. These facts show that Okun River water needs both primary and secondary treatment before it is safe for any form of consumption. Therefore, indiscriminate discharge of industrial effluent into
Okun River should be discouraged and discontinued henceforth. The state Government through the State Environmental Agency can enact a law restricting the inhabitants against indiscriminate pollution of the river by the industrialists. The community as well should be vigilant and prosecute anyone caught causing the pollution.

\section{Acknowledgment}

The authors acknowledged Department of Industrial Chemistry University of Ilorin, Ilorin, Nigeria for making available laboratory equipment. Appreciation also goes to the Technologists of the department for their technical support in the course of this research work. Thanks also go to Dr. Issa O. Sanusi Acting H.O.D., Department of Linguistics Nigerian Languages, University of Ilorin, Ilorin for the editorial assistance.

Table 8: Correlation matrix of the physiochemical properties of Okun River

\begin{tabular}{lllllllll}
\hline & $\mathbf{p H}$ & Temp & ECS & Turbidity & TSS & TDS & $\begin{array}{l}\text { Total } \\
\text { Hardness }\end{array}$ & Chloride \\
\hline pH & 1 & 0.13004 & -0.05299 & -0.22741 & 0.29554 & -0.03907 & 0.81684 & 0.22451 \\
Temp & 0.13004 & 1 & 0.24358 & 0.59008 & -0.12934 & 0.25435 & 0.45103 & 0.13458 \\
ECS & -0.05299 & 0.24358 & 1 & 0.24358 & 0.59008 & -0.12934 & 0.25435 & 0.45103 \\
Turbidity & -0.22741 & 0.59008 & -0.30006 & 1 & 0.48657 & -0.30382 & 0.08618 & -0.34738 \\
TSS & 0.29554 & -0.12934 & -0.69386 & 0.48657 & 1 & -0.71735 & 0.3227 & -0.48027 \\
TDS & -0.03907 & 0.25435 & 0.99598 & -0.30382 & -0.71735 & 1 & 0.06946 & 0.93283 \\
& & & & & & & & 0.24626 \\
Total & 0.81684 & 0.45103 & 0.09475 & 0.08618 & 0.3227 & 0.06946 & 1 & \\
hardness & & & & & & & & 1 \\
Chloride & 0.22451 & 0.13458 & 0.92827 & -0.34738 & -0.48027 & 0.93283 & 0.24626 & \\
\hline
\end{tabular}




\section{References}

AbdulJameel, A., Sirajudeen, J. \& Abdulvahith, R. (2012): Studies on heavy metal pollution of ground water sources between Tamilnadu and Pondicherry, India. Advances in Applied Science Research, 3(1):424-429.

Aboyeji, O.S. (2013): Freshwater Pollution in Some Nigerian Local Communities, Causes, Consequences and Probable Solutions. Academic Journal of Interdisciplinary Studies MCSER Publishing, Rome-Italy 2(13): 111117.

Ada, F.B., Ayotunde, E.O. \& Offem, B.O. (2012): Surface and Ground Waters Concentrations of Metal Elements in Central Cross River State, Nigeria, and their Suitability for Fish Culture. International Journal of Environment and Sustainability ISSN 1927 - 9566, 1(2): 9 -20.

Adefemi, S.O. \& Awokunmi, E.E. (2010): Determination of Physicochemical Parameters and Heavy metals in water samples from Itaogbolu area of Ondo State, Nigeria. African Journal of Environmental Science and Technology 4(3):145-148.

Adewoye, S.O. (2013): Seasonal Assessment of Impact of Industrial Effluent Discharges on the Water Quality of Asa River, Ilorin Nigeria. International Journal of Research in Environmental Science and Technology, 3(2): 65-70.

Akaninwor, J., Wegwu, M. \& Nwaichi, E. (2009). Levels of Some Heavy Metals and Physico Chemical Properties of Effluents from a Beverage Company in Rivers State, Nigeria. Journal of Applied Sciences and Environmental Management, doi:10.4314/jasem.v11i1.46829

11(1).

Akl, A.A., Dawy, M.B. \& Serage, A.A. (2014): Efficient Removal of Phenol from Water Samples Using Sugarcane Bagasse Based Activated Carbon. Journal of Analytical Bioanalytical techniques, 5: 189 doi:10.4172/2155-9872.1000189.

Anazawa, K., Kaida, Y., Shinomura, Y., Tomiyasu, T. \& Sakamoto, H. (2004). Heavy-Metal Distribution in River Waters and Sediments around a "Firefly Village", Shikoku, Japan: Application of Multivariate Analysis.
Analytical Sciences, 20(1), 79-84. doi:10.2116/analsci.20.79

Boyacioglu, H. (2007). Surface water quality assessment using factor analysis. Water SA, 32(3). doi:10.4314/wsa.v32i3.5264

Campbell, S. \& Peterson, S. (2010): Determination of water hardness from common water sources using flame atomic absorbance spectrometry. Concordia College Journal of Analytical Chemistry 1, p4-8.

Chu, K., Liu, W., She, Y., Hua, Z., Tan, M., Liu, X. \& Jia, Y. (2018). Modified Principal Component Analysis for Identifying Key Environmental Indicators and Application to a Large-Scale Tidal Flat Reclamation. Water, 10(1), 69. doi:10.3390/w10010069

Emmanuel, T. O. \& Chukwudi, N.E. (2013): Impact of urbanization on Nwaorie and Otamiri Rivers in Owerri, Imo State, Nigeria. Advances in Environmental Research 04/2013; 2(2):22341722.

Etim, E.U. \& Onianwa, P.C. (2013): Impact of Effluent of an Industrial Estate on Oruku River in South-Western Nigeria. World Applied Sciences Journal 21(7):1075-1083, 2013.

FEPA, (2001): S.I9 National Environmental Protection (Pollution Regulation in Industry and Facility generating wastes). Regulation FEPA, pp. 25-30.

Hagedorn, B. (2008): Acid Digestion of waters for total recoverable metals (following EPA METHOD 3005). Applied Science, Engineering, and Technology Laboratory University of Anchorage Alaska, pp2-14.

Hanchang, S. (2009): Industrial WastewaterTypes; Amounts and effects. China: Vol IEncyclopaedia of Life Support System (EOLSS).

Ikhajiagbe, B., Kekere, O., Omoregbee, O. \& Omokha, F.I. (2014): Microbial and Physiochemical Quality of Effluent Water from a Brewery in Benin City, Midwestern Nigeria. Journal of Scientific Research \& Reports (3): 514-531.

Jimoh, H. I. \& Iroye, K.A. (2010): Managing High Runoff Discharge in the Urbanized Basins of Asa River Catchment Area of Ilorin, Nigeria. Canadian Social Science 6(4):210-223. 
Kar, D., Sur, P., Mandal, S.K., Saha, T. \& Kole, R.K. (2008): Assessment of heavy metal pollution in surface water. International Journal of Environmental Science and Technology., 5 (1): 119-124.

Kisku, G. C., Markandeya, Kushwaha, H. \& Arora, S. (2016). Environmental Health Risk Estimation of Heavy Metals Accumulated in Soil and Cultivated Plants Irrigated with Industrial Effluents. Advances in Recycling \& Waste Management, 01(01). doi:10.4172/24757675.1000107

Lokhande, R.S., Singare, P.U. \& Pimple, D.S. (2011). Pollution in water of Kasardi River flowing along Taloja Industrial area of Mumbai, India. World Environment 1(1):6-13. DOI: 10.5923/j.env.20110101.02

Olaniyi, I., Raphael, O. \& Nwadiogbu, J.O. (2012): Effect of Industrial Effluent on the Surrounding Environment. Archives of Applied Science Research, 4 (1):406-413.

Okoro, H. K., Fatoki, O.S., Adekola, F.A., Ximba, B. J. \& Snyman, R.G. (2013): Physicochemical characteristics and One-year monitoring of heavy metal pollution in Seawater from Cape Town Harbour and their Seasonal Variation, Fresenius Environmental Bulletin, Germany. 22(10); Pp. 2855-2866, Published by Technical University of Munich, Germany. In collaboration with Parlar Research \&Technology (PRT); PRT Publishing (Scimago group)- Vimy Str.1e - 85354 Freising Germany.

URL: http://hdl.handle.net/11189/2019.

Okoro, H. K., Ayika, S.O., Ngila, J. C. \& Tella, A.C. (2018): Rising Profile on the Use of Metal-Organic Frameworks (MOFs) For the Removal of Heavy Metals from The Environment: An Overview. Applied Water Science. Springer Science Business Media. 8;169. Available at https://doi.org/10.1007/s13201-018-0818-3.

Okoro, H. K., Ige, J.O., Iyiola., O.A. \& Ngila, J.C. (2017): Fractionation profile, mobility patterns and correlations of heavy metals in estuary sediments from Olonkoro River, in tede catchment of western region, Nigeria. Environmental Nanotechnology, Monitoring \& Management. Elsevier Inc., Science Direct Academic Press.8; 53-62. Available online at https://doi.org/10.1016/j.enmm.2017.04.003.

Onwughara, N. I., Umeobika, U. C., Obianuko, P. N. \& Iloamaeke, I. M. (2011): Emphasis on Effects of Storm Runoff in Mobilizing the Heavy Metals from Leachate on Waste Deposit to Contaminate Nigerian Waters: Improved Water Quality Standards International Journal of Environmental Science and Development, 2(1): 55-63.

Oriola, E. \& Bolaji, S. (2012): Urban Flood Risk Information on a River Catchment in a Part of Ilorin Metropolis, Kwara State. Nigeria. Information and Knowledge Management, ISSN 2224-5758 (Paper) ISSN 2224-896X (Online) Vol 2, No.8.

Shen, F., Mao, L., Sun, R., Du, J., Tan, Z. \& Ding, M. (2019). Contamination Evaluation and Source Identification of Heavy Metals in the Sediments from the Lishui River Watershed, Southern China. International Journal of Environmental Research and Public Health, 16(3), 336. doi:10.3390/ijerph16030336

Singh, R. (2012). Impact of Sewage and Industrial Effluents on Soil-Plant Health. Industrial Waste. doi: $10.5772 / 37403$

USEPA, (2009): National Recommended Water Quality Criteria. Office of Science and Technology (4304T), p1-21.

Wahl, B. \& Peters, F. (2014). Effect of climatic changes on stratification and deep-water renewal in Lake Constance assessed by sensitivity studies with a 3D hydrodynamic model. Limnology and Oceanography, 59(3), 1035-1052. doi:10.4319/1o.2014.59.3.1035

WHO Geneva, (2008): Guidelines for drinkingwater quality (electronic resource), 3rd edition incorporating 1st and 2nd addenda, Volume 1, Recommendations. 